\title{
THE APPLICATION OF LANGUAGE LEARNING STRATEGIES OF HIGH SCHOOL STUDENTS IN INDONESIA
}

\author{
Alfian \\ Sulthan Thaha Saifuddin State Islamic Institute Jambi, Indonesia \\ (alfian_len@yahoo.com)
}

Received: $13^{\text {th }}$ August 2016; Revised: $14^{\text {th }}$ October 2016; Accepted: $20^{\text {th }}$ December 2016

\section{ABSTRACT}

The purpose of this study is to investigate language learning strategies (LLS) use by high school students in Indonesia. By employing a mixed-method design, eighty participants responded to the Strategy Inventory of Language Learning (SILL) questionnaire for the quantitative data. Eight language learners were interviewed for qualitative data. The descriptive statistics using SPSS was used to analyze the questionaire, and thematic analysis was used to analyze the interviews. The results indicated that first; metacognitive, cognitive and social strategies use were reportedly employed the most frequently of all strategies. Second, the strategies employed by males participants are not different with those employed by females Third, successful students used more strategies than those of less successful students. The interview findings demonstrated that successful language learners mostly used practicing strategies ( practice four language skills). This study provides the implication for classroom practice, especially raising teacher's awareness of their teaching methodology.

Key Words: gender; high school; language learning strategies (LLS); successful learners and less successful learners; SILL

\begin{abstract}
ABSTRAK
Tujuan dari penelitian ini adalah untuk mengetahui strategi-strategi pembelajaran bahasa yang digunakan oleh siswa SMA di Indonesia. Penelitian ini menerapkan metode mix-method dimana Delapan Puluh telah mengisi angket strategi belajar bahasa (SILL) untuk data kuantitatif dan Delapan siswa telah diwawancarai untuk data kualitatif. Data dari angket dianalisa dengan SPSS sedangkan metode analisis tematik digunakan untuk menganalisis hasli wawancara. Hasil penelitian ini menunjukkan bahwa pertama; Metakognitif, kognitif dan strategi sosial dilaporkan paling sering digunakan dari semua strategi pembeljaran bahasa. Kedua, strategi yang digunakan oleh siswa lakilaki tidak berbeda dengan yang laporkan oleh siswa perempuan. Ketiga, siswa yang sukses dalam pembelajaran bahasa menggunakan lebih banyak strategi daripada siswa yang kurang sukses. Dari hasil wawancara didapatkan bahwa pelajar bahasa yang berhasil kebanyakan menggunakan strategi berlatih (berlatih empat keterampilan bahasa). Penelitian ini memberikan implikasi untuk proses belajar mengajar dalam kelas, terutama untuk meningkatkan kesadaran guru terhadap pemilihab metodologi pengajaran mereka.
\end{abstract}

Kata Kunci: jenis kelamin; sma; strategi belajar bahasa (LLS); peserta didik yang sukses dan peserta didik yang kurang berhasil; SILL

How to Cite: Alfian. (2016). The Application of Language Learning Strategies of High School Students In Indonesia. IJEE (Indonesian Journal of English Education), 3(2), 140-157 doi:10.15408/ijee.v3i2.5509.

Permalink/DOI: http://dx.doi.org/10.15408/ijee.v3i2.5509 


\section{INTRODUCTION}

Learning English, whether in the classroom setting or a natural setting, requires strategies in order to achieve the goal of learning which is to be able to use the language well. For this reason, it is the learners responsibility to learn the strategies in learning. In fact, language learners develop their own ways and use various activities to learn consciuosly and unconsciously (Okada, Oxford, \& Abo, 1996). This ways and activities or actions in learning a language was previuosly known as Language Learning Strategies (LLS) (Khosravi, 2012; Grainger, 2012; Oxford, 1990, 2003).

LLS has been categorized into several classification by the experts in learning language Rubin (1987), Chamot $(1987,2004)$ and Chamot and O'Malley (1994); Ellis, 1994; Oxford, 1990; Wenden 1991. One of the most comprehensive and complete classifications is the classification by Oxford $(1990,1995)$. She first places the strategies into the two broad categories proposed by Rubin - direct and indirect strategies. However, unlike Rubin's direct strategies which consist of the cognitive and metacognitive, Oxford's direct strategies consist of three parts memory strategies, cognitive strategies, and compensation strategies. Her indirect strategies include metacognitive strategies, affective (emotional, motivation-related) strategies, and social strategiesin. In this case, Oxford also separates the social/ affective strategies of Chamot and O'malley (1994). ) into two independent categories; affective and social.

Oxford's model has been developed into questionaire which is called SILL, or Strategy Inventory for Language Learning, and has been widely used all over the world to conduct language learning strategy research. SILL is the preferred model because it provides a clear hierarchical organization. It also cover a lot of strategy. Moreover, the categories are comprehensive, appealing, and unique (Purpura, 1999).

The LLS categories and LLS in general plays a very essential role in the language learning process. It represents one of the most critical components in language learning. LLS is "especially important for language learning because they are tools for active, selfdirected movement, which is essential for developing communicative competence" (Oxford, 1990, p.1). Furthermore, Gursoy (2010) who has stated that LLS can also create a productive, student-centred learning environment in which students are encouraged to be autonomous or independent learners - learners who 
can take control of their learning (Benson, 2001; Dickinson, 1995; Hsiao \& Oxford, 2002).

Since LLS has significance role in language learning, research on language learning strategies has been conducted by focusing on several related factors, such as gender, age, performance test scores, and cultural background, proficiency level (Alfian, 2015; Oxford \& Erhman, 1995; Levine, Reves, \& Leaver, 1996; Kidd \& Marquardson, 1996; Kaylani, 1996 Khosravi, 2012; Griffiths, 2003; AlOtaibi, 2004 ; Holt, 2005).

One of the focuses of the learning strategies research was to exam whether the learner's proficiency is influenced by the use of specific strategies and the strategy use by successful learners. Holt (2005) conducted a study which investigated the relationship between language learning strategies and language performance for Chinese students who study at universities in the United States of America. He found that there is a significant difference between proficient learners and less proficient learners. The learners with a high level of English proficiency use almost all the language strategies more often. The most common category used was the compensation strategy which includes guessing meaning from context, using synonyms, and using gestures to convey meaning if the precise expression is uncertain in the conversation. This research supported the research conducted by Griffiths (2003). Griffiths' research investigates the relationships between strategy use and students' course level. He found out that the higher the level of a language learner the more frequent their use of strategies.

Oxford and Erhman (1995) state that proficiency has a significant correlation with the strategies used especially cognitive strategies. However, they observed that not all strategies affect the proficiency of language learning. There are several possible reasons. First, learners may not use other strategies, such as metacognitive and social strategies frequently. Second, the number of use strategy used might reflect the proficiency of the student. The third reason is probably that other kinds of strategies, besides the cognitive deepprocessing behaviors, might be relatively surface-level actions that can be learned more easily, and hence are more randomly scattered among the learners which makes them difficult to pinpoint.

Unlike Oxford and Erhman (1995), Song (2004) found that metacognitive strategies were most 
frequently used by the students when comparing to cognitive strategies. Furthermore, this study also showed that the more strategies the learners use, the better they score on the College English Test Band 4. This finding is supported by the researchers who state that the strategies the learners use are correlated to language performance and proficiency (Al-Otaibi, 2004; Baker and Boonkit 2004; Chamot \& O'Malley, 1994; Griffiths, 2003; Holt, 2005; Oxford and Erhman, 1995).

Another research study which was done by Oxford (1996) shows that successful language learners use many strategies, such as metacognitive, cognitive, memory, and compensation strategies in learning a language. Metacogntive strategies, as explained above, include organizing, evaluating, and planning the learning. Cognitive strategies involve analyzing, reasoning, transferring information, taking notes, and summarizing. Compensation strategies entail guessing or inferring, and memory strategies use grouping and structure reviewing.

Arce (2001) studied sixth to ninth grade Spanish language students. She categorized them as being successful if they scored $85 \%$ or higher in their course and less successful if they scored $70 \%$ or lower. She found that there was no notable difference in strategy use between the two groups. Arce's participants rarely used cognitive and metacognitive strategies. This contradicts the conclusions of Oxford and Erhman (1995), who found among adults at the Foreign Service Institute that cognitive strategies are used more often and have a significant correlation with students' language proficiency. This difference may imply the importance of a learner's age in his or her choice of and ability to use various strategies.

Another research focus in LLS was related to gender differences (Kobayashi 2002). However, according to Chaves (2001), the conclusions inferred from these studies are limited. It is important, also, when studying the differences in male and female approaches to methods of learning, to take into consideration the cultural context, general human, social, and cognitive development because males and females have great amount of differences. Hybels-Weaver (2006) argues that females and males have different listening habits or styles of audio processing. Oxford (1993a) cited in Kaylani (1996) states that "females are more interested in social activities than are males; females tend to prefer less aggressive interaction than males; likewise, females are less competitive 
and more cooperative than males" (p.79).

Gender differences have also been observed in academic and in personal or social self-efficacy. According to Wigfield, Eccles, and Pintrich (1996), females have equal confidence in mathematics during elementary school; whereas males are more efficacious than females in middle school. In contrast, females and males have similar confidence in the language and arts fields. Females show a greater achievement in languages and display better planning and goal-setting strategies, keep better records, and selfmonitor more frequently. Gender differences in learning can be minimized and even eliminated when learners use the language and seek feedback about their capabilities and progress (Pajares, 2002).

Dreyer and Oxford (1996) state that women and men use different strategic patterns. Strategic patterns are the explicit plans designed to improve one's performance. Females use such strategies more often than males, particularly metacognitive strategies such as planning tasks and organizing and evaluating progress based on set goals. In contrast to metacognitive and cognitive strategies, social strategies are put to equal use by females and males. In other words, research shows no differences of social strategies used by female and males (Kaylani, 1996). This suggests that both males and females display similar social conduct within the context of target language learning. On the other hand, Bidjerano (2005) investigates gender difference in selfregulated learning. He found that female students used more rehearsal, organization, metacognition, time management, elaboration, and effort in learning than males. He also found that there are no significance differences between males and females in terms of peer-studying, help-seeking, and critical thinking. It is clear that females' success in learning is based on their organization skills and their more frequent use of metacognitive strategies.

A study by Nyikos (1990) concluded that understanding the individual variations in completing a task, such as how one learns mathematics or a new language, is by examining identifiable groups, namely, male and female. She insists that men and women may have radically different strategies in the area of verbal learning. Females commonly have strong verbal skills, including speech ability, articulation, and fluency. Chaves (2001) states that female foreign language students are generally more successful than male students. These 
studies imply that males and females acquire new languages in different manners using different strategies. In other words, language learners may use different learning strategies selectively. In fact, in certain instances, each learner has his or her own set of learning strategies and uses them differently in terms choice and regularity (Chamot \& Kupper,1989). This differences between male and females preferences in using LLS need to be investigated in another culture context.

Therefore, based on the learners variation in language learning presented in the background of this study, this study investigates the LLS use by EFL high school students in Indonesia. Specifically, this study was conducted in order to find out the most LLS use of the SILL model's six learning strategies (Oxford, 1990), to exam the differences between male and female learning strategy preferences, exam the difference of the strategy use between successful (with scores $80 \%$ or higher) and less successful (with scores $70 \%$ or lower) students, and to investigate the strategies that the students report from the interview.

\section{METHOD}

This study employed quantitative analysis of a translated survey questionnaire supported by follow-up interviews. Supporting quantitative data with qualitative data improves the overall quality of the research (Johnson \& Christensen, 2004). Eighty students from two high schools in Indonesia responded to the the Strategy Inventory for Language Learning (SILL) questionaire version 7.0 (Oxford 1990). Eight successfull and less succesful students were interviewed. The participant were in their third year (grade 12) and have studied English for more than five years. It is intended that the sample from each school will consist of 20 of those students scoring $80 \%$ or more which were categorized as successful learners, and 20 of those students scoring $70 \%$ or less which were categoorized as less successful learners on each school's final English exam from grade 11 . There were 80 students in all.

Data analysis from surveys was done by using the SPSS (Statistical package for the Social Science) version 9.0. The $\mathrm{t}$-test will be used to provide a statistical comparison across more than two groups: males and females, high scoring and low scoring students (Pavkov and Pierce, 2003). The interview results will be analyzed by thematic analysis (Seidman, 2006). The interviews were transcribed, coded by 
content and categorized into the LLS theory.

\section{FINDINGS AND DISCUSSION Findings}

This section discusses the findings of the research, which are presented according the four research objectives.

The most strategy use of the SILL

The descriptive statistics was run to find the percentagge of strategy use in the six LLS groupings mentioned, the results show that strategies use by participants in this study from the least to the most in six-strategy. This use of strategies in the six categories is summarised in Table 3.

Table 1 shows that the metacognitive strategies are most frequently used by the students. Thirtyfour out of 80 students, or $43 \%$, prefer the metacognitive strategies. Social strategies rank second at $21 \%$. The third and fourth ranking strategies preferred by the students are compensation at $14 \%$ and memory at $13 \%$ respectively. The strategies least commonly used by the students are affective at $5 \%$ and cognitive at $4 \%$.

\section{The Use of Strategies by Gender}

T-test was run in order to find out the different of the strategy use between males and females, the results are presented in table 2 below. Based on the t-test, comparing males and females, the results show that there is no significant statistical difference between strategy preferences as described in table 2. Significant statistical difference is achieved when the $p$ value is less than $.05(p<.05)$.

Table 1. Strategies used in the six categories by students

\begin{tabular}{lll}
\hline Strategies & Number of students & $\mathbf{\%}$ \\
\hline Memory strategies & 10 & 13 \\
Cognitive strategies & 3 & 4 \\
Compensation strategies & 11 & 14 \\
Metacognitive strategies & 34 & 43 \\
Affective strategies & 5 & 5 \\
Social strategies & 17 & 21 \\
\hline Total & $\mathbf{8 0}$ & $\mathbf{1 0 0}$ \\
\hline
\end{tabular}


Table 2. Independent-Sample T test comparing average use of strategies between males and females.

\begin{tabular}{|c|c|c|c|c|c|c|}
\hline Strategies & GENDER & $\mathbf{N}$ & Mean & $\begin{array}{l}\text { Std. } \\
\text { Deviation }\end{array}$ & $\mathbf{t}$ & Df \\
\hline Memory & $\begin{array}{l}\text { Male } \\
\text { Female }\end{array}$ & $\begin{array}{l}30 \\
50\end{array}$ & $\begin{array}{l}3.42 \\
3.51\end{array}$ & $\begin{array}{l}.52 \\
.58\end{array}$ & -.75 & 78 \\
\hline Cognitive & $\begin{array}{l}\text { Male } \\
\text { Female }\end{array}$ & $\begin{array}{l}30 \\
50 \\
\end{array}$ & $\begin{array}{l}3.39 \\
3.4 \\
\end{array}$ & $\begin{array}{l}.53 \\
.58 \\
\end{array}$ & -.075 & 78 \\
\hline Compensation & $\begin{array}{l}\text { Male } \\
\text { Female }\end{array}$ & $\begin{array}{l}30 \\
50\end{array}$ & $\begin{array}{l}3.59 \\
3.33\end{array}$ & $\begin{array}{l}.58 \\
.69\end{array}$ & 1.70 & 78 \\
\hline Metacognitve & $\begin{array}{l}\text { Male } \\
\text { Female }\end{array}$ & $\begin{array}{l}30 \\
50\end{array}$ & $\begin{array}{l}3.78 \\
3.89\end{array}$ & $\begin{array}{l}.81 \\
.62\end{array}$ & -.66 & 78 \\
\hline Affective & $\begin{array}{l}\text { Male } \\
\text { Female }\end{array}$ & $\begin{array}{l}30 \\
50\end{array}$ & $\begin{array}{l}3.2 \\
3.37\end{array}$ & $\begin{array}{l}.55 \\
.69\end{array}$ & -1.18 & 78 \\
\hline Social & $\begin{array}{l}\text { Male } \\
\text { Female }\end{array}$ & $\begin{array}{l}30 \\
50\end{array}$ & $\begin{array}{l}3.53 \\
3.76\end{array}$ & $\begin{array}{l}.67 \\
.60\end{array}$ & -1.59 & 78 \\
\hline
\end{tabular}

${ }^{* *} p<.01 \quad * p<.05$

Table 3. Independent-Sample $\mathrm{T}$ test comparing average use of strategies between successful and less successful students in highly regarded high school.

\begin{tabular}{|c|c|c|c|c|c|c|}
\hline Strategy & $\begin{array}{l}\text { Success } \\
\text { Level }\end{array}$ & $\mathbf{N}$ & Mean & $\begin{array}{l}\text { Std. } \\
\text { Deviation }\end{array}$ & $\mathbf{t}$ & $d f$ \\
\hline \multirow[t]{2}{*}{ Memory } & $S$ & 20 & 3.52 & .48 & \multirow{2}{*}{$2.59^{*}$} & \multirow{2}{*}{38} \\
\hline & $\mathrm{U}$ & 20 & 3.19 & .33 & & \\
\hline \multirow[t]{2}{*}{ Cognitive } & $S$ & 20 & 3.55 & .59 & \multirow{2}{*}{$2.51^{*}$} & \multirow{2}{*}{38} \\
\hline & $\mathrm{U}$ & 20 & 3.16 & .37 & & \\
\hline \multirow{2}{*}{ Compensation } & $S$ & 20 & 3.52 & .61 & \multirow{2}{*}{-.45} & \multirow{2}{*}{38} \\
\hline & $\mathrm{U}$ & 20 & 3.60 & .55 & & \\
\hline \multirow[t]{2}{*}{ Metacognitive } & $S$ & 20 & 4.08 & .57 & \multirow{2}{*}{$2.81^{* *}$} & \multirow{2}{*}{38} \\
\hline & $\mathrm{U}$ & 20 & 3.42 & .89 & & \\
\hline \multirow[t]{2}{*}{ Affective } & $S$ & 20 & 3.32 & .62 & \multirow{2}{*}{-.01} & \multirow{2}{*}{38} \\
\hline & $\mathrm{U}$ & 20 & 3.32 & .61 & & \\
\hline \multirow[t]{2}{*}{ Social } & $S$ & 20 & 3.82 & .56 & \multirow{2}{*}{1.58} & \multirow{2}{*}{38} \\
\hline & $\mathrm{U}$ & 20 & 3.51 & .67 & & \\
\hline
\end{tabular}


Table 4. Independent-Sample t-test comparing average use of strategies between Successful and less successful students in less favored high school.

\begin{tabular}{|c|c|c|c|c|c|c|}
\hline Strategy & $\begin{array}{l}\text { Student's } \\
\text { Category }\end{array}$ & $\mathbf{N}$ & Mean & $\begin{array}{l}\text { Std. } \\
\text { Deviation }\end{array}$ & $\mathbf{t}$ & $d f$ \\
\hline \multirow[t]{2}{*}{ Memory } & $S$ & 20 & 3.36 & .53 & \multirow{2}{*}{$-2.69^{*}$} & \multirow{2}{*}{38} \\
\hline & $\mathrm{U}$ & 20 & 3.86 & .64 & & \\
\hline \multirow[t]{2}{*}{ Cognitive } & $S$ & 20 & 3.22 & .54 & \multirow{2}{*}{$-2.42^{*}$} & \multirow{2}{*}{38} \\
\hline & $\mathrm{U}$ & 20 & 3.65 & .58 & & \\
\hline \multirow[t]{2}{*}{ Compensation } & $S$ & 20 & 3.11 & .61 & \multirow{2}{*}{-1.75} & \multirow{2}{*}{38} \\
\hline & $\mathrm{U}$ & 20 & 3.49 & .78 & & \\
\hline \multirow[t]{2}{*}{ Metacognitive } & $S$ & 20 & 3.76 & .45 & \multirow{2}{*}{$-2.24^{*}$} & \multirow{2}{*}{38} \\
\hline & $\mathrm{U}$ & 20 & 4.13 & .59 & & \\
\hline \multirow[t]{2}{*}{ Affective } & $S$ & 20 & 3.04 & .48 & \multirow{2}{*}{$-2.45^{*}$} & \multirow{2}{*}{38} \\
\hline & $\mathrm{U}$ & 20 & 3.54 & .78 & & \\
\hline \multirow[t]{2}{*}{ Social } & $S$ & 20 & 3.55 & .58 & \multirow{2}{*}{-1.39} & \multirow{2}{*}{38} \\
\hline & $\mathrm{U}$ & 20 & 3.83 & .70 & & \\
\hline
\end{tabular}

\section{Use of Strategies by English Proficiency}

The researchers ran independent sample t-tests to compare the average learning strategy uses of the successful to those of the less successful students in each school. The results are presented in table 3 . The table shows the data analysis of the students from the highly reputed high school. The table reveals statistically significant differences $(p<.05)$ in three of the six categories, that is, metacognitive, cognitive, and memory respectively. The successful students use memory, cognitive, and metacognitive strategies noticeably more often than the less successful students in this school. In fact, data revealed that metacognitive strategies were statistically significant at the $p<.010$ level, which indicates extreme significance.

Table 4 presents the analysis of data in the least esteemed high school. It displays t-test results comparing successful and the less successful students in this school. The table shows significant statistical differences $(p<$ .05 ) in four of the six categories, that is, memory, cognitive, metacognitive, and affective strategies. It is surprising that, in this school, less successful students are reported using these four strategies more often than successful students. 


\section{The Strategies that the Students Report from the Interview}

The students interviewed used different strategies in improving their reading, listening, speaking, and writing skills as they could be seen in table 5 .

Table 5. Themes emerging from the interviews

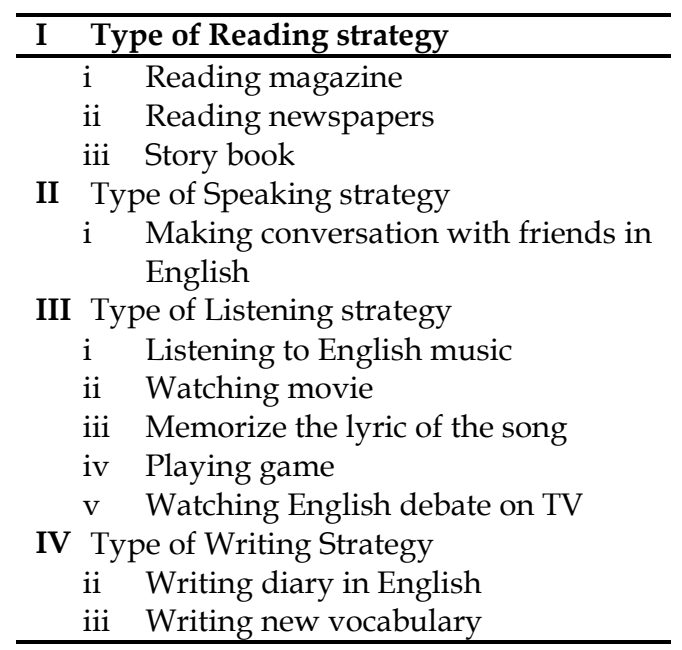

The strategies these students use to improve their English differ from student to student and skill level to skill level. However, one interesting finding from the interviews is that one less successful language learner is much less aware of the learning strategies she used. One of the questions the researcher asked was, "What language learning strategies can help you to improve language proficiency?" This participant answered, "I don't use strategies." However, when the researcher then asked how she studies
English, she answered by watching TV and listening to the radio. This participant reflects the broader trend of less successful students who were interviewed.

Another important finding is that the less successful learners do not use many different strategies in learning English. The successful learners answered the interview questions much more completely. They report using more strategies than the less successful learners. The findings from the sixteen personal interviews do support other SILL survey research results. This also contradicts with the findings from questionnaire data in less favored high school.

\section{Discussion}

The results of this study indicated that the most strategies use was metacognitive and social strategies. This supports the finding of most studies in language learning strategies in which the most strategy use by the language learners was metacognitive strategies (Al-Otaibi, 2004; Baker and Boonkit 2004; Chamot \& O'Malley, 1994; Griffiths, 2003; Holt, 2005; Oxford and Erhman, 1995). This indicates that Indonesian high school students prefer learning English by managing, monitoring and evaluating their 
learning and supporting language learning by making intereaction with other learners of English users (Oxford, 1990). Students using metacognitive strategies in their English studies usually plan, arrange, and evaluate their learning. Aside from metacognitive strategies, students find many ways to use their English. Students also like to learn English through interaction with other people, especially native speakers. Not only do students learn the language but they also learn the speaker's culture. This is a useful strategy in learning English since learning a language is very closely related with learning the culture.

In terms of the use of strategies by gender, the finding of this study indicated that there is no significant statistical difference between strategy preferences. In another words, there were no significant values, both males and females tended to improve their learning by utilizing some mixture of all the strategies. For example, male and females tend to improve their learning by building social networks and managing their learning environments as well as being involved in the target language. The findings of this study contradict the past studies in which past studies have revealed that females tend to use more strategies than males (Hong-Nam and Leavell, 2006; Oxford,
1990; Oxford \& Ehrman, 1995; Oxford and Burry-Stock, 1995; Politzer, 1983; Oxford and Nyikos, 1989). Although there is no significant differences between males and females in the strategy use, the differences can be seen from the mean score of each strategy category in which females use more strategies than those of the males.

Reagarding to the use of strategies for English proficiency, the analysis indicated that the students from the highly reputable high school reveals statistically significant differences $(p<.05)$ in three of the six categories, that is, metacognitive, cognitive, and memory respectively. The successful students use memory, cognitive, and metacognitive strategies noticeably more often than the less successful students in this school. In fact, data revealed that metacognitive strategies were statistically significant at the $p<.010$ level, which indicates extreme significance. While the results from the analysis of the data in the least esteemed high school displays that there is significant statistical differences $(p<.05)$ in four of the six categories, that is, memory, cognitive, metacognitive, and affective strategies. It is surprising that, in this school, less successful students are reported using these four strategies more often than successful students. 
The frequent usage of cognitive strategies by more successful students in refuted high school support the research of O'Malley and Chamot (1990) and Oxford (1990). Cognitive strategies are classified as direct strategies. This means that students use methods such as summarizing and reasoning which enable them to increase their English skills through many different means (Oxford, 1990). Examples of cognitive strategies include speaking, receiving and sending messages, analyzing, and creating structure for input and output, such as taking notes, summarizing, and highlighting.

Beside, cognitive strategies, memory strategies are also frequently used by the students in highly regarded high school. Memory strategies are also categorized into direct strategies which means students used the strategies by involving themselves in the target language. In memory strategies, students try to recall and learn the language by memorizing the language. The way of memorizing the language being learnt can be by grouping, using imagination and employing action (Oxford, 1990).

The successful language learners at the highly reputed school also report using metacognitive strategies more frequently than any other strategy and was highly significant. Metacognitive strategies are categorized as indirect strategies, which mean that students appear to manage their learning process and plan, organize, focus, and evaluate their own learning (Oxford, 1990; Borkowski et al., 1987). A student using metacognitive strategies will create learning plan for him/herself. For example, he/she may establish his/her personal learning style, then organize objectives and set goals. Furthermore, he/she will evaluate his/her progress through, perhaps, self-evaluation.

In term of the use of the strategies between succesful and less succesful learners, most previous research shows that successful language learners typically use more strategies than less successful language learners (Song, 2004; Griffiths, 2003; Oxford 1996). The findings from the least favored high school are also opposite to the results found in the highly regarded high school in this study.

Regarding to the the strategy reported from the interview, the findings demonstrated that the strategies that the students use to improve their English differ from student to student and skill level to skill level. However, all the strategies the students use fit into Chamot's and Oxford's LLS models. For example, most of the students conversed with 
their friends in order to improve their speaking abilities. This exercise is classified under social strategies. Meanwhile, the students who read magazines or newspapers to better comprehend written English must infer and summarize the content of their readings as they go and are therefore using a cognitive strategy. The students who take notes or write in their diaries are also using cognitive strategies.

Students report that they improve their verbal comprehension skills by listening to music and watching movies. They try to remember the conversations and expressions they hear, and, in this way, are using metacognitive strategies. So, the eight students interviewed report using mainly the cognitive, social, and metacognitive strategies. Two of these type of strategies, cognitive and metacognitive had significant differences in the questionnaire data in highly regarded high school. Therefore, the interview data lend support to the questionnaire result.

From the interview result it seems also that students do not report additional strategies that fall outside the SILL questionnaire and model. This may be because the participants of the study are high school students who have to learn at least 12 different subjects a week and thus, might not have enough time to develop other strategies. It is also likely that students do not consciously define the learning strategies they are using and therefore will not know how to expand on the process. This is because they are not taught specifically about the potential strategies they can use to study English. Another reason students do not use a wider variety of strategies may be because not all EFL students wish to become fluent and so do not use English in their daily lives (Oxford and Burry-Stock, 1995).

\section{CONCLUSION AND SUGGESTION}

This research explores language learning strategies of high school students studying English as a foreign or second language in Indonesia. The findings show first that a majority of students use metacognitve most frequently in their learning. However, they report using all six strategies. Second, there is no significant difference between male and female language learning strategy preferences. The males and females of this study use each of the strategies with a similar frequency. Third, there are significant statistical differences between successful and less successful learners in the highly reputed high school. Successful learners used more strategies than less successful learners, 
particularly memory, cognitive, and metacognitive. Fourth, there are significant differences between the successful and the less successful learners in the least esteemed high school. Less successful students in that school use more strategies than successful students. Finally, the interview result support that cognitive strategies and metacognitive strategies are use by most successful students.

It can be concluded from these results that first, English students should use all strategies particularly cognitive and metacognitive strategies. Less successful language students should model the successful ones and use similar strategies for language acquisition. Furthermore, English teachers should include in their curriculum the idea of consciously using strategies to improve foreign language study and retention and should encourage their students to practice strategies regularly.

Second, the awareness of how students approach assigned tasks in foreign language study might help teachers better meet and understand students' needs and methods of learning. At the same time, teachers may decide to introduce students to new strategies and approaches. This will expand the students' learning potential.
Third, teachers also need to be aware of the strategies used by less successful students, and should model strategies that can help them in learning. Therefore, teaching students how to use strategies will better meet students learning needs. However, the teaching of strategies means that new curriculum and materials need to be created.

Fourth, this study's conclusions generally support previous research conducted using the same questionnaire in countries such as the USA, China, Korea, Japan, and Saudi Arabia. It is recommended that further study on language learning strategies could be conducted on the spesific skills, such as, strategy use in improving speaking, reading, writing, listening and writing.

\section{REFERENCES}

Al-Otaibi, G,N. (2004). Language learning strategy use among Saudi EFL students and its relationship to language proficiency level, gender and motivation. Dissertation. Indiana: Indiana University of Pennsylvania. Retrieved on February, 2006 from http:// micro189.lib3.hawaii.edu:2132/di ssertations/dlnow/3129188. 
Arce, M. G. (2001). Foreign language learning strategies among middle school students: An exploratory study. Dissertation. Canada: The university of Mempis. Retrieved on February, 2006 from http:// micro189.lib3.hawaii.edu:2132/di ssertations/dlnow/3027958.

Benson, P. (2001). Autonomy in language learning. Harlow: Longman.

Bidjerano, T. (2005). Gender differences in self-regulated learning. Paper presented at the $36^{\text {th }}$ Annual meeting of the Northeastern Educational research association, Kerhonkson, NY.

Baker, W. \& Boonkit, K. (2004). Learning strategies in reading and writing: EAP Contexts. RELC Journal, 35 (3), 299-328. Retrieved on October 3, 2006 from http://micro189.lib3. hawaii.edu:4062/ehost/results? vid=6\&hid $=117 \&$ sid $=3$ aa9 9 bac9 8e99-4324-956f-a797d4d68fea \% 40sessionmgr102.

Chamot, A,U. (2004). Issues in language learning strategy research in teaching. Electronic Journal yof Foreign Language Teaching, 1(1), 14-26. Retrieved on March 22, 2006 from http://e-flt.nus. edu.sg/v1n12004/chamot.htm.
Chamot, A.U. (1987). Learner strategies in language learning. In Anita Wenden and Joan Rubin, (Eds). Learner strategies in language learner. New York: Prentice/Hall international.

Chamot, A. U., \& Kupper, L. (1989). Learning strategies in foreign language instruction. Foreign Language Annals, 22, 13-24.

Chamot, A.U \& O'Malley, J,M. (1994). The CALLA Handbook: Implementing the cognitive academic language learning approach. Massachusetts: Addison Wesley.

Chaves, M. (2001). Gender in the language classroom. Boston: The McGraw-Hill Companies, Inc.

Dreyer, C \& Oxford, L.R. (1996). Learning strategies and other predictor of ESL proficiency among Afrikaans speakers in South Africa. In Oxford, R,L (Ed). Language strategies around the world (pp. 61-74). Honolulu: Language Teaching and Curriculum Center, University of Hawaii.

Dickinson, L. (1995). Autonomy and motivation a literature review. System, 23(2), 165-174. doi: http://dx.doi.org/10.1016/0346 -251X(95)00005-5. 
Grainger, P. (2012). The impact of cultural background on the choice of language learning strategies in the JFL context. System, 40(4), 483493.doi: http://dx.doi.org/10. 1016/j.system.2012.10.011.

Griffiths, C. (2003). Patterns of language learning strategy use.System, 31, 367-383.

Gursoy, E. (2010). Investigating language learning strategies of EFL children for the development of a taxonomy. English Language Teaching, 3(3), P164.

Hsiao, T. Y., \& Oxford, R. L. (2002). Comparing Theories of Language Learning Strategies: A Confirmatory Factor Analysis. The Modern Language Journal, 86(3), 368-383. doi: 10.1111/15404781.00155 .

Holt, K. (2005). English proficiency of Chinese students and strategies of language learning. Dissertation. Kansas: University of Kansas. Retrieved on March, 2006 from http://micro189.lib3.hawaii.edu:2 132/dissertations/dlnow/318779 4.

Hybels-Weaver. (2006). English language institute: Advanced listening speaking. University of Hawaii At Manoa: McGraw- Hill.

Johnson, B. \& Christensen, L. (2004). Educational research: Quantitative, qualitative, and mixed approaches. Boston: Pearson Education, Inc.

Kaylani (1996). The influence of gender and motivation on EFL learning strategy use in Jordan. In R. L. Oxford, (Ed.), Language strategies around the world ( pp. 75-78). Honolulu: Language Teaching and Curriculum Center, Univer sity of Hawaii.

Kobayashi, Y. (2002). The role of gender in foreign language learning Attitudes: Japanese female student's towards English learning. Gender and Education, 14(2), 181-197.

Khosravi, M. (2012). A Study of Language Learning Strategies Used by EFL Learners in Iran: Exploring Proficiency Effect on English Language Learning Strategies. Theory and Practice in Language Studies, 2(10), 2122-2132.

Levine, Reves, \& Leaver. (1996). Relationship between language learning strategies and Israeli versus Russian cultural educational factors. In Oxford, R,L (Ed.). Language strategies around the world (pp.35 - 45). Honolulu: Language Teaching and Curriculum Center, University of Hawaii. 
Nyikos, M. (1990). Sex-Related Differences in Adult Language Learning: Socialization and Memory Factors. Modern Language Journal, 74 (3), 273-287.

Okada, M., Oxford, R. L. \& Abo, S. (1996). Not all alike: Motivation and learning strategies among students of Japanese and Spanish in an exploratory study. In Oxford (Ed.). Language learning motivation: Pathways to the new century. Honolulu: University of Hawaii: Second language teaching and curriculum center.

Oxford, R.L. (1996). Why is culture important for language learning strategies? Language Teaching and Curriculum Center. Honolulu: University of Hawaii.

Oxford, R. L. (1993). Research on second language learning strategies. Annual Review of Applied Linguistics, 13, 175 - 187.

Oxford, R.L. (1990). Language learning strategies: what every teacher should know. New York: New Bury House Publishers.

Oxford, R.L. \& Burry-Stock, J. A. (1995). Assessing the use of language learning strategies worldwide with the ESL/EFL version of the Strategy Inventory for Language Learning (SILL). System, 23 (1), 1-23.

Oxford, R. L. \& Ehrman, M. E. (1995). Adults' language learning strategies in an intensive foreign language program in the United States. System, 23(3), 359-386.

Oxford, R. L. \& Nyikos, M. (1989). Variables affecting choice of language learning strategies by university students. The Modern Language Journal, 73 (3), 291- 300.

Pajares, F. (2002). Gender and perceived self -efficacy in self regulated learning. Theory in Practice, 41(2), 116-125.

Pavkov, T. W. \& Pierce, K.A. ( 2003). Ready,set,go!: A student's guide to SPSS 11.0 for windows. New York: McGraw-Hill.

Purpura, J. E. (1999). Strategy use and second language performance: theories and empirical research. In M. Milanovic (Ed.), Studies in language testing. Hillsdale, N.J.: Cambridge University Press.

Rubin, J. (1987). Learner strategies in language learning. In A. Wenden and J. Rubin, (Eds.), Learner strategies in language learner. New York: Prentice/Hall International. 
Seidman, I. (2006). Interviewing as qualitative research: A guide for researchers in education and the social sciences. New York: Teachers College press.

Song, X . (2004). Language learning strategy use and language performance for Chinese learners of English.Dissertation. Canada: Queen's University. Retrieved on March, 2006 from http:// micro189.lib3.hawaii.edu:2132/di ssertations/dlnow/MQ99642.
Wenden, A. (1991). Learner strategies for learner autonomy: Planning and implementing learner training for language learners. New York: Prentice Hall.

Wigfield, A, Eccles, J.S., \& Pintrich, P.R. (1996). Development between the ages of 11 and 25. In D. C. Berliner, \& R. C. Calfee, (Eds.), Handbook of Educational Psychology (pp. 148-1850). New York: Simon \& Schuster Macmillan. 